\title{
Target populations for direct-drilled ryegrass and tall fescue
}

\author{
J-P. PRAAT ${ }^{1}$, W.R. RITCHIE ${ }^{2}$, C.J. BAKER ${ }^{2}$ and J. HODGSON ${ }^{3}$ \\ ${ }^{1}$ Lincoln Technology, Ruakura, Private Bag 3062, Hamilton \\ ${ }^{2}$ Centre for International No-tillage Research and Engineering, Nannestead Line, RD 5, Feilding 5600 \\ 3 Plant Science Department, Massey University, Palmerston North
}

\section{Abstract}

Establishment, botanical composition and production of direct-drilled perennial ryegrass and tall fescue were compared for two seeding rates in an autumn-sown, grazed trial. Tall fescue (Festuca arundinacea Schreb. cv. AU Triumph) was sown at either 17 or $31 \mathrm{~kg} / \mathrm{ha}$ and perennial ryegrass (Lolium perenne L. cv. Grasslands Supernui) was sown at 12 and $23 \mathrm{~kg} / \mathrm{ha}$ on 12 April, 1990 all with "Grasslands Pitau" white clover at $3 \mathrm{~kg} / \mathrm{ha}$. Measurements of herbage mass and botanical composition during the ensuing 2-year period showed that there was no advantage in terms of suppression of weed species or accumulation of herbage mass of the sown species from sowing more seed than that required to achieve a population of $450-500$ plants $/ \mathrm{m}^{2}$ of either ryegrass and tall fescue 6 weeks after sowing. A population of 150 white clover plants $/ \mathrm{m}^{2}$ appeared to be adequate for development of a balanced sward. Establishment of fescue was slower than that of ryegrass but both species developed to productive swards after infrequent but close defoliation with dairy cattle in the first spring and subsequent rotational grazing by lactating dairy cows. Pasture establishment in Northland is difficult because of shallow topsoils. Direct drilling can preserve this fragile topsoil and successfully establish alternative species such as fescue as long as attention is paid to their establishment requirements. Alternative species may offer a solution to low feed availability of ryegrass in the summer and poor survival of ryegrass in poorly drained areas during the winter.

Keywords: direct drilling, Festuca arundinacea, Loliumperenne, pasture establishment, seeding rate

\section{Introduction}

Tall fescue (Festuca arundinacea Schreb.) provides a useful alternative to perennial ryegrass (Lolium perenne L.) in situations where insect damage and/or dry summer conditions (Milne \& Fraser 1990) limit the performance of traditional ryegrass-based pastures. The use of tall fescue on New Zealand farms has increased in recent years, but its uptake by farmers has been hampered by its slow growth during establishment. Direct drilling has become a common method for establishment of ryegrass among dairy farmers as it conserves time, soil structure and consolidation, and often reduces the direct cost. Alternative species have also been successfully established by direct drilling (Milneet al. 1993) although reports are variable (McCallum \& Thomson 1990).

Traditionally, seeding rates in tilled seedbeds have been high $(25-40 \mathrm{~kg} / \mathrm{ha}$ ) in order to suppress weeds in developing swards (Cullen \& Meeklah 1959), to compensate for poor seedling emergence rates (Cross 1959; Ritchie 1986), and have been shown to depress the yield of slower establishing companion species (Culleton et al. 1986). High sowing rates have also been used in an attempt to ensure the survival of introduced species when oversowing or drilling into unsprayed pasture, and to compensate for poor drilling technique (Thorn et al. 1985; Ritchie 1986). Brougham (1 954b) and Ritchie (I 986) suggested that seeding rates should show closer resemblance to equilibrium populations of established pasture. Practical recommendations based on target populations provide a useful basis on which to base decisions on seeding rate (Turner 1992).

There are few critical assessments of seeding rate effects on direct-drilled (no-till) ryegrass and tall fescue under grazing conditions. This report describes successful establishment of tall fescue and ryegrass by direct drilling, and concentrates on the influence of seed rate and vigour of the sown species on the botanical composition and production of the resulting pasture.

\section{Materials and methods}

The trial reported here formed part of a wider study which considered drilling method effects on pasture establishment (Praat 1995) and will be reported more fully elsewhere. Two species, perennial ryegrass (cv. Grasslands SuperNui) and tall fescue (cv. AU Triumph) were sown on at No. 1 Dairy Farm, Massey University, Palmerston North. on an alluvial soil (Manawatu fine sandy loam). The trial site had medium fertility and there was no requirement for lime.

The trial area was sprayed with $2.16 \mathrm{I} / \mathrm{ha}$ glyphosate as active ingredient ( 6 1/ha Roundup@). A relatively 
high rate was required to control couch (Elytrigia repens L. Nevski) and temperate $\mathrm{C}_{4}$ grasses. Granstar $($ was tank-mixed with Roundup@ at a rate of $30 \mathrm{~g} / \mathrm{ha}(22.5 \mathrm{~g} /$ ha tribenuron methyl as active ingredient) to control clover. Seven days later the area was hard grazed to remove as much existing vegetation as possible and harrowed to disperse dung pats. Twenty-one days later (12 April, 1990) the trial was direct drilled with a Aitchison Seedmatic 1100 fitted with "Baker boot" inverted $\mathrm{T}$ openers preceded by discs. Sowing depth was $20 \mathrm{~mm}$. Target populations were 1000 and 500 plants $/ \mathrm{m}^{2}$ for the two seeding rates. Actual seeding rates achieved in the field were 17 and $31 \mathrm{~kg} / \mathrm{ha}$ for tall fescue and 12 and $23 \mathrm{~kg} / \mathrm{ha}$ for ryegrass. Seed was treated with fungicide $(120 \mathrm{~g}$ of $80 \%$ captan $100 \mathrm{~kg}$ seed) but uncoated. White clover (Trifolium repens $c v$. Grasslands Pitau) was drilled with the grass at $3 \mathrm{~kg} / \mathrm{ha}$ over the whole trial area. Phorate $($ was placed in the seed groove at a rate of $5 \mathrm{~kg} / \mathrm{ha}(1 \mathrm{~kg} / \mathrm{ha}$ phorate as active ingredient) for grass grub control. After harrowing, $10 \mathrm{~kg} / \mathrm{hagranular}$ Blitzem $\otimes$ mollusicide $(0.27$ $\mathrm{kg}$ metaldehyde/ha) was applied. No post-emergence herbicide was used.

Seeding rate and species were combined in a randomised split plot factorial design with 6 replicates. Species formed the main plots with seeding rate as the sub-plots. Sub-plot size was $7 \times 7 \mathrm{~m}$ with $6 \mathrm{~m}$ borders.

Grazing management was divided into 2 stages: establishment (0-276 days after sowing (d.a.s.)) where short hard grazings (target stubble height of $40-60 \mathrm{~mm}$ in 8-14 hours grazing) with young dairy cattle were used (Ritchie 1986; Thorn et al. 1987), and the production phase (276-684 d.a.s.) where the trial area was grazed by lactating dairy cows in the normal rotation of the farm. Fescue and ryegrass plots were grazed simultaneously, except for the first grazing when only ryegrass was grazed at 54 d.a.s.. The seed-heads of ryegrass and tall fescue were topped to maintain palatability after spring grazings where required.

Seedling density measurements were made on all species 37-42 d.a.s. The number of sown species in six $0.4 \mathrm{~m}$ row lengths were counted in each plot. Clover and weed species density was assessed in three $0.7 \mathrm{~m}^{2}$ quadrats per plot. Herbage mass and composition were determined by cutting to ground level in at least 3 quadrats per plot. Herbage from sub-samples of quadrat cuts was dissected into component species and dead material 8 times during the trial period. All herbagc material was washed, before drying and weighing.

\section{Results}

The drill performed well on the comparatively flat conditions of the trial area and the target seed depth of
$20 \mathrm{~mm}$ after harrowing was achieved for both species. Average emergence for ryegrass and fescue was 84 and $71 \%$ of viable seeds respectively (Table 1). The seeding rate of tall fescue was increased by $10 \%$ to compensate for the lower field emergence than ryegrass which was expected for a mid April sowing (K. Hill, pers comm. 1990). This adjustment resulted in similar populations of both species for both seeding rates (Table 1).

Table 1 Effects of species and seeding rate on percentage emergence and population at 42 days after sowing.

\begin{tabular}{|c|c|c|c|}
\hline Species & $\begin{array}{c}\text { Seeding } \\
\text { Rate }\end{array}$ & $\begin{array}{c}\text { Nominal Seedling } \\
\text { Emergence } \\
\text { (\% of viable seeds) } \ddagger\end{array}$ & $\begin{array}{l}\text { Population } \\
\text { (plants/m-*) }\end{array}$ \\
\hline Fescue & $\begin{array}{l}\text { HIGH } \\
\text { LOW }\end{array}$ & $\begin{array}{l}68 \\
73\end{array}$ & $\begin{array}{l}814 \\
489\end{array}$ \\
\hline $\begin{array}{l}\text { SED } \pm \\
\text { Significance }\end{array}$ & & $\begin{array}{c}3 \\
\text { n.s. }\end{array}$ & $\begin{array}{r}28 \\
\cdot \square \square\end{array}$ \\
\hline Ryegrass & $\begin{array}{l}\text { HIGH } \\
\text { LOW }\end{array}$ & $\begin{array}{l}78 \\
91\end{array}$ & $\begin{array}{l}778 \\
485\end{array}$ \\
\hline $\begin{array}{l}\text { SED } \pm \\
\text { Significance }\end{array}$ & $\neq$ & $\begin{array}{l}3.5 \\
* * *\end{array}$ & $\stackrel{25}{\cdot}$ \\
\hline
\end{tabular}

- $\ddagger$ Nomenclature for level of probability in this and other tables

(*) $^{*}=10 \% \cdot=5 \% *^{*}=1 \% \cdot *^{*}=0.1 \%$ n.S. $=$ not significant

More white clover seedlings were present in the fescue than the ryegrass plots (Table 2) which would be expected given the less vigorous establishment of tall fescue than of ryegrass. However, overall emergence for white clover was only $46 \%$ of viable seed (average 168 white clover seedlings $/ \mathrm{m}^{*}$ ) which is comparable to results of Thorn et al. (I 993). Neither species nor seeding rate had a significant effect on the population of unsown species (Table 2). On average $67 \%$ of unsown species were broadleaf weeds while $33 \%$ were grass weeds. As there were no interactions between species and seeding rate, only main effects are presented in Table 2 .

Table 2 Effect of species and seeding rate on population of white clover and unsown species seedlings.

\begin{tabular}{lcc}
\hline Species & $\begin{array}{c}\text { White Clover } \\
\text { (plants/m }\end{array}$ & $\begin{array}{c}\text { Total } \\
\text { (plants } / \mathbf{m}^{-2)}\end{array}$ \\
\hline Fescue & 190 & 652 \\
Rye & 146 & 603 \\
SED \pm & 13.5 & 46 \\
Significance & $\star$ & n.S. \\
\hline Seeding Rate & & \\
High & 184 & 628 \\
Low & 152 & 627 \\
SED \pm & 13 & 35 \\
Significance & $*$ & $n .5$ \\
\hline
\end{tabular}


Table 3 Effect of seeding rate on herbage mass of sown species at seven times during the trial period during ( $\mathrm{kg}$ DM/ha pre-graze for each date).

\begin{tabular}{|c|c|c|c|c|c|c|c|c|}
\hline Species & $\begin{array}{c}\text { Seeding } \\
\text { Rate }\end{array}$ & $\begin{array}{c}54 \\
(6.6 .90)\end{array}$ & $\begin{array}{c}147 \\
(9.9 .90)\end{array}$ & $\begin{array}{c}219 \\
(21.11 .90)\end{array}$ & $\begin{array}{r}393 \\
(15.5,91)\end{array}$ & $\begin{array}{c}496 \\
(28.8 .91)\end{array}$ & $\begin{array}{rr}5 & 7 \\
(9.11 .91)\end{array}$ & $\begin{array}{c}684 \\
(6.3 .91)\end{array}$ \\
\hline Fescue & $\begin{array}{l}\text { HIGH } \\
\text { LOW }\end{array}$ & $\begin{array}{c}\text { N/At } \\
\text { N/A }\end{array}$ & $\begin{array}{l}595 \\
545\end{array}$ & $\begin{array}{l}1396 \\
1161\end{array}$ & $\begin{array}{l}1857 \\
1755\end{array}$ & $\begin{array}{l}1576 \\
1475\end{array}$ & $\begin{array}{l}1497 \\
1562\end{array}$ & $\begin{array}{l}1756 \\
1757\end{array}$ \\
\hline $\begin{array}{l}\text { SED } \pm \\
\text { Significance }\end{array}$ & & & $\begin{array}{r}68 \\
\text { n.s. }\end{array}$ & $\begin{array}{l}156 \\
\text { n.s. }\end{array}$ & $\begin{array}{l}174 \\
\text { n.s. }\end{array}$ & $\begin{array}{l}124 \\
\text { n.s. }\end{array}$ & $\begin{array}{l}118 \\
n, \$ .\end{array}$ & $\begin{array}{l}121 \\
\text { n.S. }\end{array}$ \\
\hline Ryegrass & $\begin{array}{l}\text { HI GH } \\
\text { L O W }\end{array}$ & $\begin{array}{l}274 \\
208\end{array}$ & $\begin{array}{l}974 \\
951\end{array}$ & $\begin{array}{l}2653 \\
2884\end{array}$ & $\begin{array}{l}1921 \\
2080\end{array}$ & $\begin{array}{l}1517 \\
1575\end{array}$ & $\begin{array}{l}2607 \\
2375\end{array}$ & $\begin{array}{l}1416 \\
1415\end{array}$ \\
\hline $\begin{array}{l}\text { SED } \pm \\
\text { Significance }\end{array}$ & & 21 & $\begin{array}{r}67 \\
\text { n.S. }\end{array}$ & $\begin{array}{l}272 \\
\text { n.s. }\end{array}$ & $\begin{array}{l}144 \\
\text { n.S. }\end{array}$ & $\begin{array}{l}108 \\
\text { n.s. }\end{array}$ & $\begin{array}{l}152 \\
\text { n.s. }\end{array}$ & $\begin{array}{l}100 \\
\text { n.s. }\end{array}$ \\
\hline
\end{tabular}

$+\mathrm{N} / \mathrm{A}$ - Not measured

Ryegrass yield was almost double that of tall fescue during establishment (147 and 219 d.a.s) illustrating the faster growth rate of ryegrass (Table 3 ). This was reflected by greater seedling weight and tiller number at those times (Praat 1995). Increasing the seeding rate resulted in increased herbage mass of ryegrass only at the initial grazing ( 54 d.a.s.) but this effect was not sustained.

The fescue sward initially had significantly more unsown species than ryegrass (5 I vs $31 \%$ at 147 d.a.s.) and more clover (9 vs $3 \%$ at 147 d.a.s.). By the end of the second spring, clover and unsown species contents were similar for both species at $20 \%$ and $10 \%$ respectively. After 2 years, botanical composition of ryegrass and tall fescue plots was similar. Seeding rate had negligible effects on composition of the sward.

\section{Discussion}

The results indicated that there was no agronomic gain to be had from increasing seeding rate of direct-drilled perennial pasture for dairy cattle grazing, above-that necessary to establish approximately $450-500$ plants $/ \mathrm{m}^{2}$ along with 150-170 white clover plants $/ \mathrm{m}^{2}$. There may in fact be a disadvantages in terms of percentage emergence with high seeding rates for ryegrass. A negative relationship between seeding and emergence rates for ryegrass has been reported previously (Ryan et al. 1979) but is not a general occurrence (Brougham 1954a).

The emergence of tall fescue tends to suffer more than ryegrass where conditions are less than optimal. Poor seedling vigour is commonly cited as a major failing of the species (Brock 1982). However, satisfactory results can be achieved where the conditions are right, most importantly competition control, seed depth and temperature (Brock 1973; Belloti \& Blair 1989; Charles et al. 1991).
Clover emergence is often overlooked in pasture establishment trials even though it is an important component of New Zealand's pastures. Although no specific studies are reported for the effect of seed depth on emergence of direct-drilled white clover, the optimum depth is probably less than $20 \mathrm{~mm}$, given that Campbell (1983) recommended a depth of $13 \mathrm{~mm}$ for red clover, a larger-seeded legume than white clover. Excessive seed depth was likely to have been the cause for poor clover emergence in this trial.

During the trial period, clover mostly comprised $20 \%$ of the fescue sward and never less than 10\%. Low clover content in the ryegrass sward $(3-10 \%)$ during the first year was most likely the result of higher pregrazing herbage mass which tended to occur in ryegrass, which would have caused increased competition for light and suppressed clover growth. Clover performs better when sown with tall fescue than with ryegrass (Hay 1987).

No significant "pulling" of establishing fescue plants by grazing animals occurred. This is thought to be related to the relatively firm Manawatu fine sandy loam under direct drilling, compared with cultivated seed-bed and peat soils from which pulling has been reported (Brock 1982; Prestidge et al. 1989).

Similar populations of broadleaf and grass weeds were present initially in the trial for the two species and the two seeding rates. The proportions of broadleaf and grass weeds were not affected by seeding rate in either species but were higher in fescue, showing the superior competitive ability of ryegrass against broadleaf and grass weeds. Control of weeds may need special attention when establishing tall fescue. Usually spraying with phenoxy butyrics (MCPB) is recommended early in the establishment period. Infrequent but close defoliation with dairy cattle in the first spring appeared to control weeds well and encouraged grass over weed growth in both species. Recommendations for grazing tall fescue 
vary from little and often (Charlton \& Thorn 1984) to hard and often (Turner 1992). However, subject to care at initial grazing these results suggest there is scope to treat tall fescue similarly to ryegrass, following direct drilling. Fescue was utilised as efficiently as ryegrass, indicating that it was no less acceptable to lactating dairy cows.

\section{Conclusion}

Tall fescue pastures, along with other "alternative" species on Northland farms, could well complement the feed supply derived from ryegrass-based pastures by filling some of the feed shortage over summer. Fescue has also been shown to survive better in wet soils during winter than ryegrass. Northland soils generally do not suit full cultivation as they are too shallow. They do, however, suit direct drilling establishment systems. Successful establishment of tall fescue by this method demands attention to sowing date, seeding depth and control of existing vegetation and weeds arising in the establishing pasture. The last goal may be achieved with suitable grazing management. The seed for tall fescue and other alternative species is generally more expensive than ryegrass ( $\$ 5-6$ vs \$2-3 per $\mathrm{kg}$ ), making high percentage establishment important. Seeding rates for tall fescue and ryegrass need be no higher than that required to achieve around 500 plants $/ \mathrm{m}^{2}$. Assuming efficient drilling, and 75-85\% field emergence of viable seed, a seeding rate of approximately $16-1 \quad 8 \mathrm{~kg} / \mathrm{ha}$ tall fescue and 9-1 $1 \mathrm{~kg} / \mathrm{ha}$ ryegrass should be sufficient to establish productive swards.

\section{ACKNOWLEDGEMENTS}

We thank G. Lynch, M. Power and A. Jull of Massey University No. 1 Dairy farm for providing a trial site and assisting with grazing requirements, T. Lynch, G. Evans, M. Osborne and M. Thompson for technical assistance and G. Arnold for statistical analysis. This work forms part of a $\mathrm{PhD}$ study by John-Paul Praat.

\section{REFERENCES}

Belloti, W.D.; Blair, G.J. 1989. The influence of sowing method on perennial grass establishment. III. Survival and growth of emerged seedlings. Australian journal of agricultural research 40: 323-331.

Brock, J.L., 1973. Effect of sowing depth and postsowing compaction on the establishment of Tall Fescue. New Zealand journal of experimental agriculture $1:$ 11-14.
Brock, J.L. 1982. 'Grasslands Roa' tall fescue: Dry matter production under grazing. New Zealand journal of experimental agriculture 10: 28 1-284.

Brougham, R.W. 1954a. Pasture establishment studies: I and II. New Zealand journal of science and technology A35(6): 518-38; 539-49.

Brougham, R.W. 1954b. Pasture establishment studies: IV. New Zealandjournal of science and technology A36: 365-74.

Campbell, B.D. 1985. Winged coulter depth effects on overdrilled red clover seedling emergence. New Zealand journal of agricultural research 28: 7-1 7.

Charles, G.W.; Blair, G.J.; Andrews, A.C. 1991. The effect of soil temperature, sowing depth and the seedling emergence of tall fescue (Festuca arundinacea Schreb.) and white clover (Trifolium repens L.). Australian journal of agricultural research 42: 1261-96.

Charlton, J.F.L.; Thorn, E.R. 1984. Establishment and persistence of new herbage species and cultivars. New Zealand agricultural science 18: 130-135.

Cullen, N.A.; Meeklah, F.A.H. 1959. Seeding rates and weedkillers in pasture weed control. Proceedings of the New Zealand Grassland Association 21: 54-59.

Culleton, N.; Murphy, W.E.; O'Keefe, W.F. 1986. The role of mixtures and seeding rates in ryegrass productivity. Irish journal of agricultural research 25(3): 299-305.

Hay, R.J.M. 1987. Understanding pasture growth. Proceedings of the Massey Dairy Farmers Conference 39: 55-63.

McCallum, D.A.; Thomson, N.A. 1990. Effect of a molluscicide and an insecticide on the establishment of direct-drilled ryegrass, tall fescue and phalaris. Proceedings of the New Zealand Grassland Association 52: 237-240.

Milne, G.; Fraser, T. 1990. Establishment of 1600 hectares in dryland species around Omaru/Timaru. Proceedings of the New Zealand Grassland Association 52: 133-1 37.

Milne, G.D.; Moloney, S.C.; Smith, D.R. 1993. Demonstration of dryland species on 90 east coast North Island farms. Proceedings of the New Zealand Grassland Association 55: 39-44

Praat, J-P. 1995. Row spacing and seeding rate interactions in perennial ryegrass and tall fescue swards established by direct drilling (No-tillage). PhD Thesis, Massey University, Palmerston North, New Zealand.

Prestidge, R.A.; Van der Zijpp, S.; Gault, P. 1989. Effect of Argentine stem weevil on vigour of 'Grasslands Roa' tall fescue under dairying in the Waikato. New Zealand journal of agricultural research 32: 29 1-297 
Ritchie, W.R. 1986. Pasture Renovation or Renewal? Dairy Farming Annual 1986. Publ by Massey University, pp.136-143.

Ryan, D.L.; Hay, R.J.M.; Baker, C.J. 1979. Response of some ryegrass cultivars to overdrilling in Southland. Proceedings of the New Zealand Grassland Association 41: 136-144.

Thorn, E.R.; Prestidge, R.A.; Barker, G.M. 1987. Pasture establishment on the dairy farm. Proceedings Ruakura Farm Conference 39: 50-52.
Thorn, E.R.; Wildermoth, D.D.; Taylor, M.J. 1993. Growth and persistence of perennial ryegrass and white clover direct-drilled into a paspalum-dominant dairy pasture treated with glyphosate. New Zealand journal of agricultural reerch 30 197-20 1 :

Turner, J.D. 1992. High quality pasture feed for southern New Zealand - a consequence of cultivar choice and their subsequent management. Proceedings of the New Zealand Grassland Association 54: 91-94. 